\title{
Well differentiated thyroid tumor of unknown malignant potential (WDT UMP) associated with COWDEN syndrome
}

\author{
Enaam Junainah*, Mohammed AIShanbari, Nashat Gandoura, Nadia Enani, Khalid Alnouri, Sahar Fatta, \\ Jamal Junainah, Abdulelah Sber, Saeed Alamoudi, Manal Junainah and Fawzi Junainah \\ *Correspondence: mennastar3@hotmail.com ( \\ Departments of Pathology, King Fahad general Hospital, Jeddah, Saudi Arabia.
}

\begin{abstract}
Cowden syndrome is a rare cancer predisposition syndrome inherited in an autosomal-dominant fashion. The syndrome is characterized by hamartomatous polyps that affect multiple organs: skin, mucous membranes, thyroid, breast, gastrointestinal tract, endometrium and brain. It is also associated with an increased risk of developing malignancy in many tissues but especially breast, thyroid and endometrium. Thyroid tumor is ranging from benign nodule to frank malignancy. We report a case of WDT UMP in 66 years old lady who has CS.
\end{abstract}

Keywords: WDT UMP, COWDEN syndrome, thyroid tumor

\section{Case presentation}

A 66- Year-old Saudi female patient known case of chronic bone \& joint pain on Osteopenia \& Sulfasalazine treatment following with Rheumatology. Presently complaining of neck swelling for 6 months associated with Dysphagia and shortness of breath. No history of hoarseness, no weight loss and no fever. No history of radiation exposure. No family history of thyroid carcinoma. past medical history revealed, multiple hamartomatous colonic polyp treated with endoscopic polypectomy. as well as uterine fibroid treated by hysterectomy. The following year she presented with breast nodules on two separate occasions. Surgical excision was performed on each occasion and histology on each of these occasions revealed benign fibrocystic disease of the breast.

\section{On examination}

She was found to have multiple abnormal physical findings. She had muffled face, additional skin lesions with multiple facial keratotic papules, and papillomatosis, particularly around the eyes, mouth, and ostrils, buccal mucosal papules with a 'cobblestone-like' appearance, and cutaneous verrucous papules in the acral portions of the hands, feet, palms, and soles. A breast examination revealed multiple palpable nodules. Additional physical findings included strabismus and skeletal abnormalities with kyphoscoliosis and pectusexcavatum. Ear, Nose \& Throat --> Unremarkable. Fiberoptic examination shows bilateral mobile vocal cord. Neck shows mid line neck swelling $4 \times 5 \mathrm{~cm}$ with retrosternal extension, no tender and no palpable cervical lymph nodes lab investigations all with in normal limits, including thyroid function test-Excised buccal papules sent for histologic examination revealed acanthosis papillomatosis with keratosis epiderma. A breast ultrasound examination showed bilateral nodules compatible with fibrocystic disease.

Ultrasound Neck shows right thyroid lobe is normal average size with 3 hypo echoic nodules the biggest $6 \times 4 \mathrm{~mm}$. increase in area visibility. Isthmus enlarged $5 \mathrm{~mm}$, no focal nodules. Left thyroid lobe showed lobe showed large heterogeneous, soft tissue nodules measuring $8.4 \times 5.4 \mathrm{~cm}$, occupying mid lower pole no enlarged cervical lymph node.

\section{Impression}

\section{Bilateral thyroid nodules}

CT Scan Neck also done, showing significant left thyroid lobe enlargement with reterostenal extension. No enlargement of cervical lymph seen (Figure 1) node Nodule FNA shows few group of typicalfollicular cell exhibit nuclear groove and over lopping. Patient underwent total thyroidectomy.

\section{Histopathological}

Examination of the surgically removed specimen (Figure 2) showed that Right lobe measured $4.5 \times 3.5 \times 2.5 \mathrm{~cm}$ with intact capsule. Serial sectioning revealed variable sized, well circumscribed and ill-defined nodules ranging from 0.5 to 1.5 $\mathrm{cm}$ in diameter. Cut surface was soft and brown with areas of cystic degeneration. The left lobe specimen consisted of single light brown, well circumscribed and capsulated solid nodule measuring $4.5 \times 3 \times 2 \mathrm{~cm}$ and weighing $79 \mathrm{gram}$. Serial sectioning showed areas of hemorrhage and cystic degeneration.

Microscopic examination revealed thyroid parenchyma with a well circumscribed nodule composed of closely packed follicles (Figure 3) containing scant colloid. Few areas showed variable sized follicles with abundant colloid. The follicles were lined by follicular cells. Fewareas had enlarged nuclei showing nuclear 


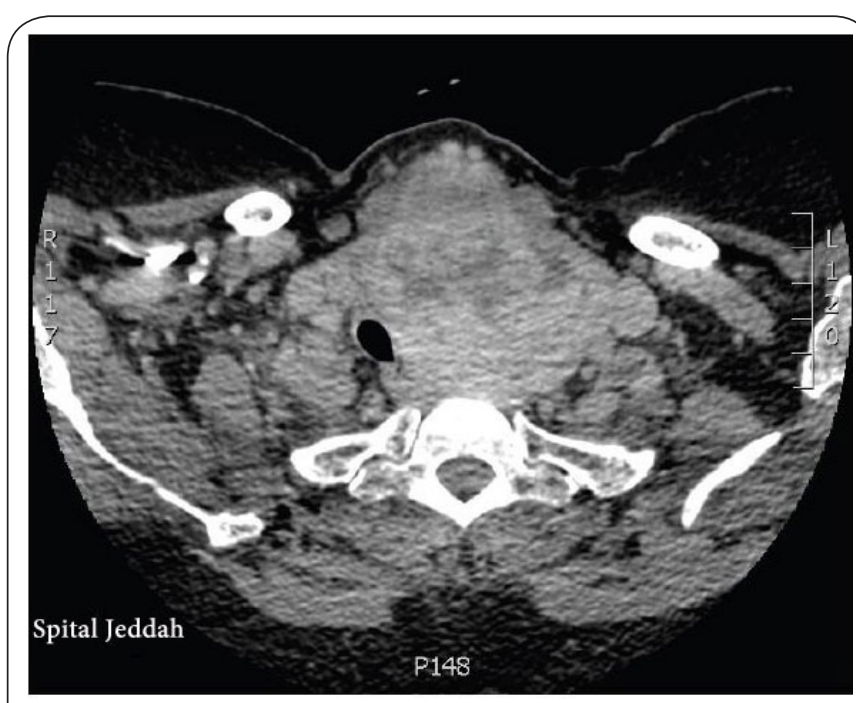

Figure 1. CT neck show left lobe heterogeneous.

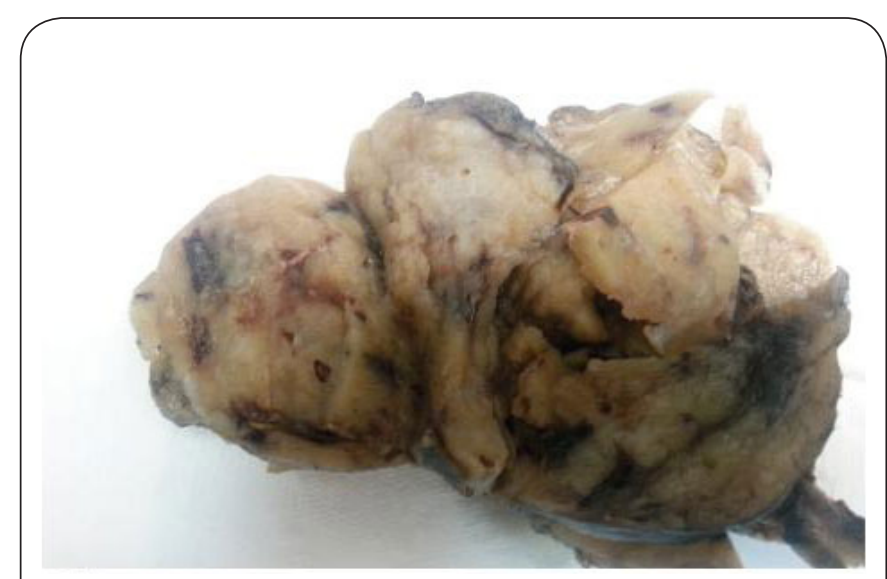

Figure 2. Macroscopic examination show encapsulated Mass with variegated appearance.

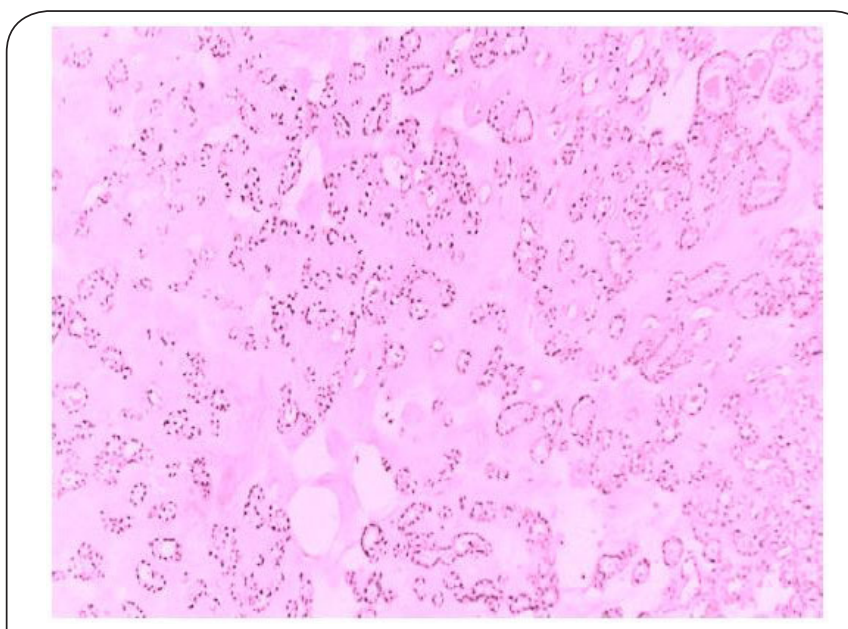

Figure 3. Low power examination, original magnification $\mathrm{x} 10$, show micro follicles lined by follicular cells with intervening hylinized stroma. clearing and mild overlapping. Scattered nuclei had nuclear grooves (Figure 4). Nuclear inclusions were not seen. Focal area show thick capsul with questionable capsular invasion (Figure 5), but no vascularin vasion noted. Cytokeratin 19 (CK 19) was positive (Figure 6), Galctin3 (Figure 7) \& HBME1 (Figure 8) show focal membranous \& cytoplasmic positivity in $30 \%$ of the cells. Other areas revealed features suggestive of multinodular goiter.

The isthmus show evidence of has himotothyroidaites. Based on findings, it was diagnosed as well differentiated tumor of uncertain malignant potential.

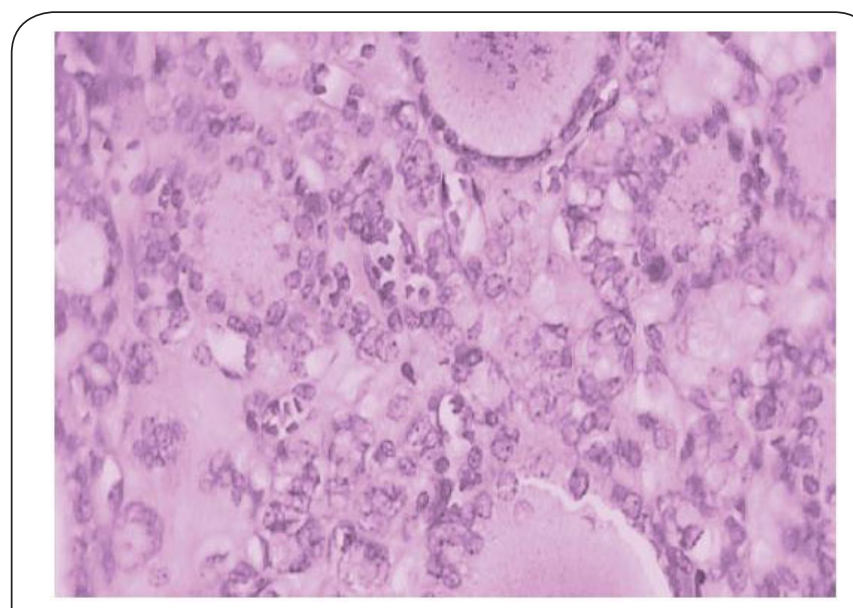

Figure 4. High power examination, original magnification $\mathrm{x} 40$, show follicles lined by follicular cells exhibit nuclear clearing, overlapping and grooves.

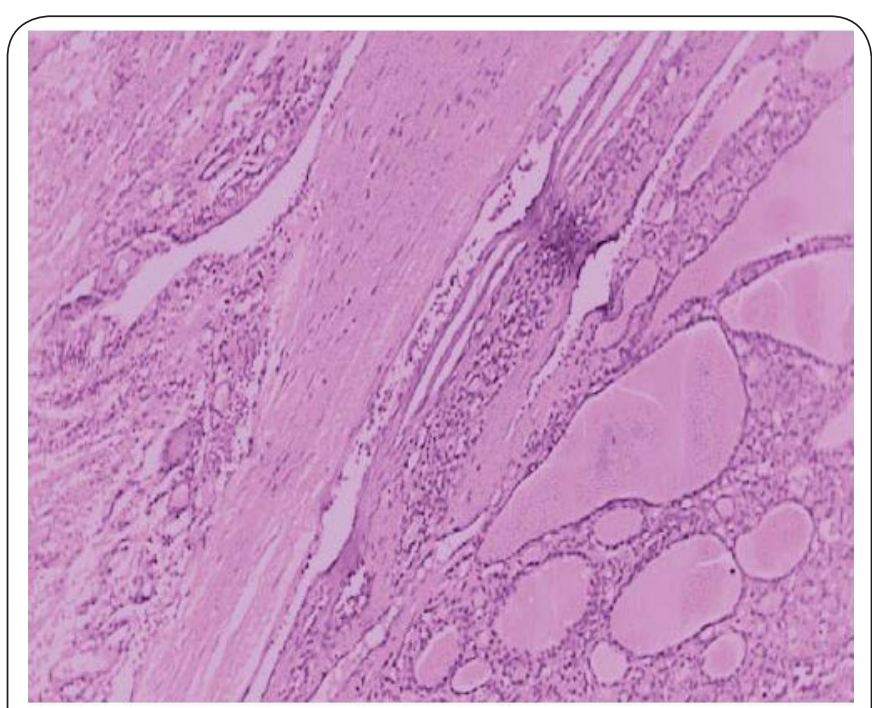

Figure 5. Low power examination, original magnification $\mathrm{x} 10$,show thick capsule with questionable capsular invasion.

Colonoscopy diagnosed diffuse colorectal polyposis with multiple lesions in the sigmoid and rectum Biopsies of these 


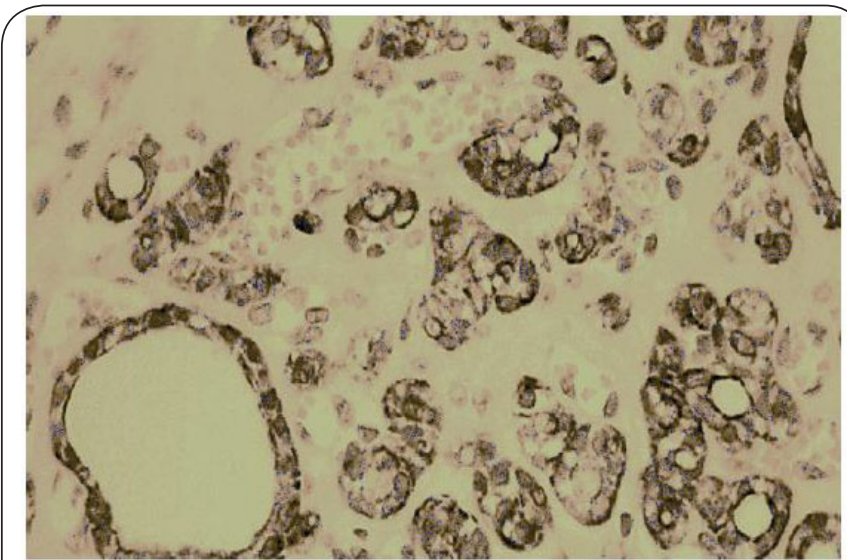

Figure 6. High power examination, original magnification $\mathrm{x} 50$ Show strong $=3$ positive membranous stain for CK19.

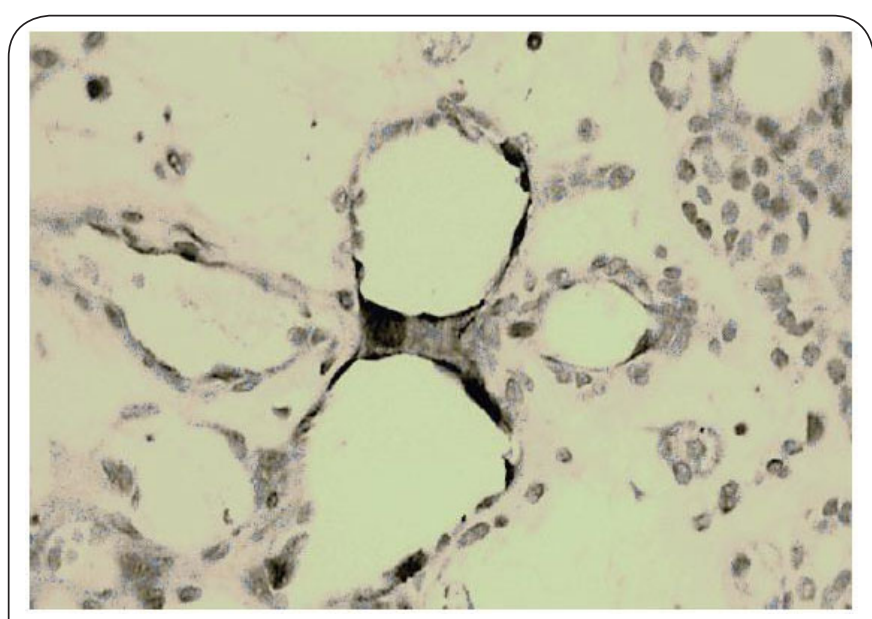

Figure 7. High power examination,original power $\mathrm{x} 40$ show focal +2 membranous and cytoplasmic positivity with Glactin 3.

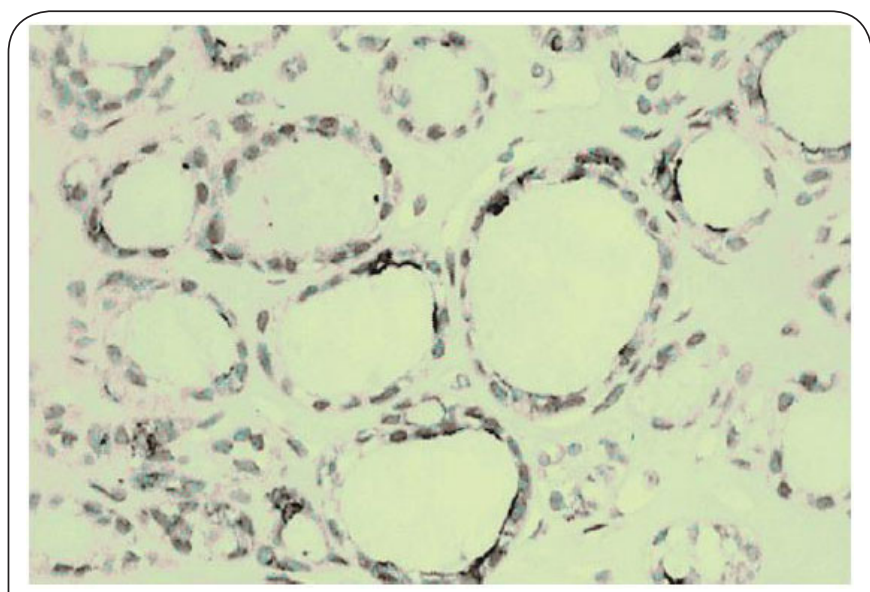

Figure 8. High power examination, original power $\mathrm{x} 40$ show focal +2 positive membranous and nuclear stain with HBME 1 .

polyps showed inflammatory and hyperplastic hamartomatous polyps. Our patient was diagnosed as having CS based on the syndrome testing criteria adapted by the US National Comprehensive Cancer Network (NCCN) [3].

\section{Discussion and literature review}

Cowden syndrome is an autosomal sdominant syndrome predisposing to cancer, characterized by the occurrence of hyperplastic hamartomatous and tumoral lesions affecting various organs [23]. The disease mainly affects Caucasian women $[24,25]$. CS is most often diagnosed during the third decade of life (age range, 13 to 65 years) [24,25].

This syndrome is characterized by a combination of ectodermal, mesodermal, and endodermal alterations that may involve various organs: the skin, mucous membranes, breast, digestive tract, thyroid, and central nervous system. The characteristic skin signs such as facial trichilemmomas, acral keratosis and mucocutaneous papillomas, occur in $99 \%$ to $100 \%$ of patients and are preferentially localized in the peri-oral and facial regions [24]. These lesions are significant for diagnosis and have little malignant potential [26]. Breast lesions with fibrocystic disease, as observed in our patient, occur in approximately $75 \%$ of women. Breast carcinoma has been described in $30 \%$ to $50 \%$ of patients, and a recent review reported an $81 \%$ lifetime risk of breast cancer in patients with CS [27]. and fibrocystic breast disease. No breast cancer was detected in our patient $[\mathbf{2 8 , 2 9 ]}$. Thyroid disease occurs in twothirds of patients including goiter, thyroiditis, and thyroid cancer. Gastrointestinal involvement may be found throughout the gastrointestinal tract, frequently in the colon, but rarely in the small bowel [30]. *Gastrointestinal involvement is predominantly in the form of hamartomatous colorectal polyps*. Other polyps such as lipomatous, fibromatous, hyperplastic inflammatory and adenomatous lesions have also been described [31]. Esophageal glycogenic acanthosis is present in $40 \%$ to $60 \%$ of patients with CS andshould be pathognomonic [31]. Until recently, it was reported that gastrointestinal involvement was not neoplastic. Heald et al., in a prospective study of 127 PTEN mutation carriers reported that $13 \%$ of patients undergoing colonoscopy were diagnosed as having colorectal cancer [33]. This study confirms that patients with CS are at increased risk for cancer.

Additional findings include abnormalities of the female reproductive tract presenting as ovarian cysts $(24 \%)$, leiomyoma (44\%), and endometrial carcinoma (10\%) [1], central nervous system tumors, ganglioneuromas, neurofibromas, intracranial hypertension, granular cell myoblastoma and meningioma have all been reported in patients with CS [23]. Skeletal abnormalities are described in $37 \%$ of patients with CS including adenoid facies, kyphoscoliosis, syndactyly, and brachyphalangia. Other abnormalities include eye dysfunction, pulmonary lipoma, lung cysts, and cardiovascular problems [32]. Our patient had many of these documented physical findings of CS including skin and oral mucosal lesions, thyroid tumor, gastrointestinal polyps, skeletal abnormalities and a history 
Junainah et al. Journal of Histology \& Histopathology 2014,

http://www.hoajonline.com/journals/pdf/2055-091X-1-1.pdf

of fibrocystic breast disease. Most patients with CS have a germ-line mutation in the tumor suppressor gene PTEN.

The role of PTEN in tumorigenesis has been demonstrated and the loss of PTEN function contributes to cellular transformation, increasing the risk of cancer development in patients at an earlier age. *The mutation is identified in only $80 \%$ of patients who meet the clinical criteria. The interesting finding in our patient that she developed thyroid follicular tumor which consider of low malignant potential, as this category of thyroid tumor been recently introduced by WHO, in which The conventional grouping of thyroid carcinoma into the main categories of papillary, follicular, medullary and anaplastic (undifferentiated) carcinomabased on morphological features according to WHO classification [1] has made the diagnosis of these entities very simple and straightforward. However, the argument arise in cases of encapsulated follicular variant of papillary thyroidcarcinoma (FVPTC) also called as Lindsay's tumor. This was described originally by Lindsay in 1960 and then later reemphasized by Chen and Rosai [3-5]. These tumors are defined as an encapsulated neoplasm of follicular cells with follicular architecture and having archetypal nuclear characteristics of papillary thyroid carcinoma (PTC). The presence of capsular and/or blood vessel invasion is not a prerequisite for making the diagnosis. On the other hand, nuclear features of papillary thyroid carcinoma in the form of clearing, overlapping, grooves and pseudo inclusions should be wide spread. Treatment of the lesions is not different from management of conventional papillary and follicular thyroid carcinoma since Chang et al., pointed out the blood born metastatic pattern of some cases of FVPTC [10]. To circumvent the low threshold of the endocrine pathologist in the diagnosis of these conditions two categories were proposed in 2000 regarding the terminology of thyroid tumors by the Chernobylpathologists group. These novel definitions were based on the fact that there are several diagnostic uncertainties in terms of recognition of certain varieties of encapsulated thyroid tumors with a follicular architecture [6-11]. Further more, there is propensity to over diagnose the entity of follicular variant of papillary thyroid carcinoma. To overcome this diagnostic dilemma, an editorial was published proposing the category of well differentiated tumor of uncertain malignant potential (WDTUMP) to include encapsulated tumors having minimal or questionable nuclear changes of archetypal papillary thyroid carcinoma but definite absence of vascular invasion. This is basically an intermediate category between benign and malignant lesion. Few studies have assessed the utility of the immunehistochemical markers to delineate these lesions in terms of benign versusmalignant category. Markers like Galectin-3 and HBME-1 [13-17] have been examined in these tumors. HBME-1 has been shown to be a better marker of malignancy but due to the small sample size it is not recommended to base our diagnosis onthese immunochemical markers $[\mathbf{1 4 , 1 5 ]}$. The authors also commented that the term as suggested by its name would not be expected to be followed by aggressive management [18-22]. This borde- rline diagnosis was also made in order to avoid unnecessary surgery or radioactive iodine (RAI) treatment putting patients at risk of complications. However, the argument given against this entity was the fact that certainly this term would also be overused by the pathologists and will create uncertainty among endocrinologists and surgeons in terms of their management. More over, the defining authors mentioned their curiosity in knowing about the cases of metastasis in tumors satisfying the criteria of well differentiated tumor of uncertain malignant potential (WDT-UMP). Due to the vagueness of the clinical behavior of these tumors, clinicians and surgeons are often puzzled regarding the treatment of these tumors. More over, there are no guidelines or protocols for the management of these tumors aswell. In the management of our case, we also encountered the similar problem and treatment uncertainty but ultimately decided to treat the patient with RAI post thyroidectomy which later on proved to be a sensible clinical decision due to the finding of pulmonary metastasis found on post RAI whole body scan. On the basis of the reported findings, it is tempting to speculate that these new entities should be treated with total thyroidectomy followed by RAI until more long term data is vailable documenting the clinical out come of these lesions.

\section{Competing interests}

The authors declare that they have no competing interests.

\section{Authors' contributions}

\begin{tabular}{|l|c|c|c|c|c|c|c|c|c|c|c|}
\hline $\begin{array}{l}\text { Authors' } \\
\text { contributions }\end{array}$ & EJ & MA & NG & NE & KA & SF & JJ & AS & SA & MJ & FJ \\
\hline $\begin{array}{l}\text { Research } \\
\text { concept and } \\
\text { design }\end{array}$ & $\checkmark$ & -- & -- & $\checkmark$ & -- & -- & -- & -- & -- & -- & - \\
\hline $\begin{array}{l}\text { Collection } \\
\text { and/or } \\
\text { assembly of } \\
\text { data }\end{array}$ & $\checkmark$ & $\checkmark$ & -- & -- & -- & -- & -- & -- & -- & -- & - \\
\hline $\begin{array}{l}\text { Data analysis } \\
\text { and } \\
\text { interpretation }\end{array}$ & $\checkmark$ & -- & -- & -- & -- & -- & -- & -- & -- & -- & -- \\
\hline $\begin{array}{l}\text { Writing the } \\
\text { article }\end{array}$ & $\checkmark$ & -- & -- & -- & -- & -- & -- & -- & -- & -- & -- \\
\hline $\begin{array}{l}\text { Critical revision } \\
\text { of the article }\end{array}$ & $\checkmark$ & -- & -- & -- & -- & -- & -- & -- & -- & $\checkmark$ & - \\
\hline $\begin{array}{l}\text { Final approval of } \\
\text { article }\end{array}$ & $\checkmark$ & $\checkmark$ & -- & $\checkmark$ & $\checkmark$ & $\checkmark$ & $\checkmark$ & $\checkmark$ & $\checkmark$ & -- & $\checkmark$ \\
\hline $\begin{array}{l}\text { Statistical } \\
\text { analysis }\end{array}$ & $\checkmark$ & -- & -- & -- & -- & -- & -- & -- & - & -- & - \\
\hline
\end{tabular}

\section{Acknowledgement}

Mohammed .S.Kurdi, Hala.meer, Enaam.Sisi, Sameera.Sugati Tahani. hamboli, and Samar. shgiri, Thanks for there contribution in collecting data and facilitate accessing to the patient date as well as helping in genetic counseling and screening.

\section{Publication history}

Editor: Gjumrakch Aliev, GALLY International Biomedical Research \& Consulting LLC, USA.

Received: 06-Feb-2014 Accepted: 25-Feb-2014

Published: 04-Mar-2014 
Junainah et al. Journal of Histology \& Histopathology 2014, http://www.hoajonline.com/journals/pdf/2055-091X-1-1.pdf

\section{References}

1. De Lellis RA, Lloyd RV and Heitz PU. Pathology and genetics: tumours and endocrine organs, 3rd edn. WHO, Geneva. 2004.

2. Williams ED. Guest Editorial: Two Proposals Regarding the Terminology of Thyroid Tumors. Int J Surg Pathol. 2000; 8:181-183. | Article | PubMed

3. Lendasy S. Carcinoma of thyroid gland: clinical and radiological study of $\mathbf{2 9 3}$ patient at university of Calforniahospital Springfield. Charles C Thomas. 1960.

4. Chem KT and Rosai J. Follicular variant of thyroid papillary carcinoma: a clinicopathologic study of six cases. Am J Surg Pathol. 1977; 1:123-30. | Article | PubMed

5. Rosai J. Handling of thyroid follicular patterned lesions. Endocr Pathol. 2005; 16:279-83. | Article | PubMed

6. Rosai J, Kuhn E and Carcangiu ML. Pitfalls in thyroid tumour pathology. Histopathology. 2006; 49:107-20. | Article | PubMed

7. Baloch ZW and Livolsi VA. Follicular-patterned lesions of the thyroid: the bane of the pathologist. Am J Clin Pathol. 2002; 117:143-50. | Article | PubMed

8. Evans HL. Follicular neoplasms of the thyroid. A study of $\mathbf{4 4}$ cases followed for a minimum of $\mathbf{1 0}$ years, with emphasis on differential diagnosis. Cancer. 1984; 54:535-40. I Article I PubMed

9. Fonseca E, Soares P, Cardoso-Oliveira M and Sobrinho-Simoes M. Diagnostic criteria in well-differentiated thyroid carcinomas. Endocr Pathol. 2006; 17:109-17. | Article I PubMed

10. LiVolsi VA and Baloch ZW. Follicular neoplasms of the thyroid: view, biases, and experiences. Adv Anat Pathol. 2004; 11:279-87. I Article I PubMed

11. Sobrinho-Simões M, Magalhaes J and Foncesa E. Diagnostic pitfalls of thyroid pathology.CurrDiagPathol . 2005; 11:52-59. I Article

12. Suster $\mathrm{S}$. Thyroid tumors with a follicular growth pattern: problems in differential diagnosis. Arch Pathol Lab Med. 2006; 130:984-8. | Article | PubMed

13. Barroeta JE, Baloch ZW, Lal P, Pasha TL, Zhang PJ and LiVolsi VA. Diagnostic value of differential expression of CK19, Galectin-3, HBME-1, ERK, RET, and p16 in benign and malignant follicular-derived lesions of the thyroid: an immunohistochemical tissue microarray analysis. Endocr Pathol. 2006; 17:225-34. | Article | PubMed

14. Coli A, Bigotti G, Parente P, Federico F, Castri F and Massi G. Atypical thyroid nodules express both HBME-1 and Galectin-3, two phenotypic markers of papillary thyroid carcinoma. J Exp Clin Cancer Res. 2007; 26:221-7. I PubMed

15. Ito $\mathrm{Y}$, Yoshida $\mathrm{H}$ and Tomoda $\mathrm{C}$. HBME-1 expression in folliculartumour of the thyroid: an investigation of whether it can be used as a marker to diagnose follicular carcinoma. Anticancer Res. 2005; 25:179-182.

16. Mase T, Funahashi H, Koshikawa T, Imai T, Nara Y, Tanaka $Y$ and Nakao A. HBME-1 immunostaining in thyroid tumors especially in follicular neoplasm. Endocr J. 2003; 50:173-7. I Article I PubMed

17. Miettinen M and Karkkainen P. Differential reactivity of HBME-1 and CD15 antibodies in benign and malignant thyroid tumours. Preferential reactivity with malignant tumours. Virchows Arch. 1996; 429:213-9. | Article | PubMed

18. LiVolsi VA. Pure versus follicular variant of papillary thyroid carcinoma: clinical features, prognostic factors, treatment, and survival. Cancer. 2003; 98:1997; author reply 1997-8. | Article I PubMed

19. Zidan J, Karen D, Stein M, Rosenblatt E, Basher W and Kuten A. Pure versus follicular variant of papillary thyroid carcinoma: clinical features, prognostic factors, treatment, and survival. Cancer. 2003; 97:1181-5. I Article | PubMed

20. Jing X, Nakamura Y, Nakamura M, Yokoi T, Shan L, Taniguchi E and Kakudo $\mathrm{K}$. Detection of Epstein-Barr virus DNA in gastric carcinoma with lymphoid stroma. Viral Immunol. 1997; 10:49-58. | Article I PubMed

21. Zuo H, Nakamura Y, Yasuoka H, Zhang P, Nakamura M, Mori I, Miyauchi A and Kakudo K. Lack of association between BRAF V600E mutation and mitogen-activated protein kinase activation in papillary thyroid carcinoma. Pathol Int. 2007; 57:12-20. | Article I PubMed

22. Kakudo K, Katoh R, Sakamoto A, Asa S, DeLellis RA, Carney JA, Naganuma $\mathrm{H}$, Kameyama $\mathrm{K}$ and Takami $\mathrm{H}$. Thyroid gland: international case conference. Endocr Pathol. 2002; 13:131-4. | Article | PubMed

23. Farooq A, Walker LJ, Bowling J and Audisio RA. Cowden syndrome. Cancer Treat Rev. 2010; 36:577-83. | Article | PubMed

24. Scheper MA, Nikitakis NG, Sarlani E, Sauk JJ and Meiller TF. Cowden syndrome: report of a case with immunohistochemical analysis and review of the literature. Oral Surg Oral Med Oral Pathol Oral Radiol Endod. 2006; 101:625-31. | Article | PubMed

25. Uppal S, Mistry D and Coatesworth AP. Cowden disease: a review. Int J Clin Pract. 2007; 61:645-52. | Article | PubMed

26. Jornayvaz FR and Philippe J. Mucocutaneous papillomatous papules in Cowden's syndrome. Clin Exp Dermatol. 2008; 33:151-3. | Article | PubMed

27. Riegert-Johnson DL, Gleeson FC, Roberts M, Tholen K, Youngborg L, Bullock $M$ and Boardman LA. Cancer and Lhermitte-Duclos disease are common in Cowden syndrome patients. Hered Cancer Clin Pract. 2010; 8:6. | Article I PubMed Abstract | PubMed Full Text

28. Kacem M, Zili J, Zakhama A, Hadj Youssef F, Mahjoub S, Boubakri C and El May M. [Multinodular goiter and parotid carcinoma : a new case of Cowden's disease]. Ann Endocrinol (Paris). 2000; 61:159-63. | Article | PubMed

29. Hachicha M, Kammoun T, Chabchoub I, Bahloul S, Turki H, Drira M, Zahaf A and Triki A. [Cowden's disease: a new paediatric observation]. Arch Pediatr. 2006; 13:459-62. | Article | PubMed

30. Farooq A, Walker LJ, Bowling J and Audisio RA. Cowden syndrome. Cancer Treat Rev. 2010; 36:577-83. | Article | PubMed

31. Trufant JW, Greene L, Cook DL, McKinnon W, Greenblatt M and Bosenberg MW. Colonic ganglioneuromatous polyposis and metastatic adenocarcinoma in the setting of Cowden syndrome: a case report and literature review. Hum Pathol. 2012; 43:601-4. | Article I PubMed

32. Lee HR, Moon YS, Yeom CH, Kim KW, Chun JY, Kim HK, Choi HS, Kim DK and Chung TS. Cowden's disease--a report on the first case in Korea and literature review. J Korean Med Sci. 1997; 12:570-5. I Article I PubMed Abstract | PubMed Full Text

33. Heald B, Mester J, Rybicki L, Orloff MS, Burke CA and Eng C. Frequent gastrointestinal polyps and colorectal adenocarcinomas in a prospective series of PTEN mutation carriers. Gastroenterology. 2010; 139:1927-33. | Article | PubMed Abstract | PubMed Full Text

Citation:

Junainah E, AlShanbari M, Gandoura N, Enani N, Alnouri K, Fatta S, Junainah J, Sber A, Alamoudi $S$, Junainah $M$ and Junainah $F$. Well differentiated thyroid tumor of unknown malignant potential (WDT UMP) associated with COWDEN syndrome. $J$ Histol Histopathol. 2014; 1:1.

http://dx.doi.org/10.7243/2055-091X-1-1 